\title{
The changing face of medical education: The impact and effectiveness of evidence generating community health project in medical students
}

\author{
Trushna Shah', Geetanjali Purohit ${ }^{2}$, Niraj Pandit ${ }^{3}$, Ajay George ${ }^{4}$ \\ ${ }^{1}$ Asst. Prof. in Department of Biochemistry, SBKS MI \& RC, Sumandeep Vidyapeeth, Piparia, Vadodara, Gujarat, India, ${ }^{2}$ Asst. Prof. in \\ Department of Physiology, SBKS MI \& RC, Sumandeep Vidyapeeth, Piparia, Vadodara, Gujarat, India, ${ }^{3}$ Prof. in Department of Community \\ Medicine, SBKS MI \& RC, Sumandeep Vidyapeeth, Piparia, Vadodara, Gujarat, India, ${ }^{4}$ Prof \& Head, in Department of ENT, SBKS MIRC, \\ Sumandeep Vidyapeeth, Piparia, Vadodara, Gujarat, India
}

\section{A B S T R A C T}

Background: Evidence-based practice usually refers to gathering quantitative data based upon the best decision about what constitutes effective or efficient practice or what is sometimes referred to as "best practices". The objective of the present study was to evaluate the student's perception and learning effectiveness towards Evidence Generating Community Health Projects (EviGenCHIP). Materials and Methods: This study was questionnaire based cross sectional study carried out in SBKS MIRC, Sumandeep Vidyapeeth, Vadodara, Gujarat, India. A total of 110 MBBS students (III Year) participated. After obtaining ethical clearance the data was collected and analyzed. Data was compiled in excel sheet, analyzed for percentage and proportion. Results: In the present study 100 students $(90.9 \%)$ believed that research in medical field is important. On the contrary $40 \%$ students believed that there is no need to know about research methodology. After Evidence Generating Community Health Projects students were sensitized to the importance of protocol writing (56.3\%), searching literature $(40.9 \%)$, structured questionnaires, data collection and its analysis $(45 \%)$, report writing $(52.7 \%)$ and presentation as an integral part of research process. Conclusion: Evidence Generating Community Health Projects canbe an effective tool for medical education, where they become exposed and sensitized to the research process at undergraduate level. It also improves active learning in public health and research skills. This teaching and learning model can be considered in other medical schools in the country.

Key words: Evidence generating community health project, Research methodology, Protocol
Access this article online Website:

http://nepjol.info/index.php/AJMS DOI: 10.3126/ajms.v6i3.10951

\section{INTRODUCTION}

Evidence based medicine (EBM) consists of conscientious, explicit and judicious use of the current best evidence in making decisions about care for individual patients. ${ }^{1}$ Evidence Generating Community Health Projects (EviGenCHIP) $^{2}$ is the part of EBM teaching in Sumandeep Vidyapeeth, where students work on community health projects and generate new evidences. The way medicine is taught and learnt has undergone tremendous changes over the past few decades. In India, efforts to orient medical students to public health research are very few or not reported yet. It has been suggested that medical colleges should provide a brief skill-based training program on community-based research as a part of the undergraduate curriculum. ${ }^{3,4}$

The active learning methods can be helpful in understanding the subjects better and to be more interesting for the students. Studies have shown the positive results with community based teaching in Mahatma Gandhi Institute of Social Sciences. ${ }^{5,6}$ One study from Sewagram reported that community based health project approach is an effective method of active learning as it involves integration of social 
sciences with medical domain, task oriented assignments and active community involvement.

EviGenCHIP projects were preceded by two days training workshop on searching skills and other research aspects. This training workshop enabled the students to understand the need of communities and relate the theoretical knowledge to practical training in a primary care context. EBM emphasize the use of evidences from well designed and conducted research in healthcare decision-making. The term was originally used to describe an approach to teaching the practice of medicine and improving decisions by individual physicians. EviGenCHIP is one of the components of EBM. The primary objective of EviGenCHIP is to sensitize the medical students in understanding community health problems, generate various levels of evidences and think to find out the solution with available resources at local set up. The objective of The aim of the present study to evaluate the student's perception and learning effectiveness towards EviGenCHIP.

\section{MATERIALS AND METHODS}

Present study was self-structured questionnaire based cross sectional study carried out in III year MBBS students, had finished their evidence based community health projects. A pilot study was conducted to validate the questionnaire in 10 dental students, as they were also following the same pattern. The results of pilot study were matched with the present study. Before the projects execution two days' workshop was conducted, where students learned how to generate evidences. After completion of EviGenCHIP they must have to prepare a synopsis and present this project in front of respective teachers and their colleagues.

As described above, all students passed through the whole process of EviGenCHIP during year 2013. They finished 24 such community projects and presented in the month of Oct 2013. The present study was aimed to evaluate the student's perception for this changing face of medical education at undergraduate level. After Ethical clearance and consent the data collection has done. The investigators were approached the students in class room during lecture hours. The prime objective of the study was to get genuine answer of all questions in context to the programme. The questions were focused on knowledge gained during workshop about research methods, development of protocol, guidance of teacher for developing protocol, data collection experience, report writing and presentation of report. All the aspects were covered to understand the learning objective of evidence generation, searching evidences, process of research.

\section{RESULTS}

Table 1 showed the general views for research in medical undergraduates. Though students were never been the part of research, $90.9 \%$ students believed that research in medical field is important. More than $60 \%$ students acquired the research concept during EviGenCHIP. Almost all students were not considered the research as a good career option means financially bad option as a doctor.

Table 2 showed the feedback on Likert scale. The questions focused on feedback of evidence based community health projects.

\section{DISCUSSION}

As a result of exposure of EviGenCHIP students agreed that they became sensitized to protocol write up $(56.3 \%)$, searching literature $(40.9 \%)$, data collection and analysis (45\%), report writing $(52.7 \%)$ and presentation as an integral part of research process. ${ }^{8}$ Students also perceived that team research is better than individual research and it develop their communication skills. A good training is known to improve the awareness and skills of medical students and develop a positive attitude towards research. ${ }^{9,10}$ Students agreed that they would be able to apply, what they learned in Evi Gen CHIP Workshop, in future research work.

The Indian Council of Medical Research (ICMR) has been awarding Short Term Studentship (STS) Program to selected deserving medical undergraduates for research skills improvement. ${ }^{11}$ The similar term 'Problem Solving for Better Health' (PSBH), a global movement by Dreyfus health foundation, sensitizing medical students

\begin{tabular}{|c|c|c|}
\hline Questions & Yes $[N(\%)]$ & No [N(\%)] \\
\hline $\begin{array}{l}\text { Do you think research in } \\
\text { medical field is important? }\end{array}$ & $100(90.9)$ & $10(9.09)$ \\
\hline $\begin{array}{l}\text { Have you ever been part of a } \\
\text { research? }\end{array}$ & $20(18.8)$ & 90 (81.18) \\
\hline $\begin{array}{l}\text { With this workshop of } \\
\text { EviGenCHIP, do you think that } \\
\text { you acquired the research } \\
\text { concept? }\end{array}$ & $70(63.6)$ & $40(36.3)$ \\
\hline $\begin{array}{l}\text { Is evidence based community } \\
\text { health project is useful to you? }\end{array}$ & $62(56.3)$ & $48(43.6)$ \\
\hline $\begin{array}{l}\text { Did you make an attempt to } \\
\text { publish your research? }\end{array}$ & $12(10.9)$ & 98 (89.09) \\
\hline $\begin{array}{l}\text { Would you take up research } \\
\text { as your career option? }\end{array}$ & $05(4.54)$ & $105(95.45)$ \\
\hline
\end{tabular}




\begin{tabular}{|c|c|c|c|c|c|}
\hline \multirow[t]{2}{*}{ Questions } & \multicolumn{5}{|c|}{$(n=110)$} \\
\hline & $\begin{array}{c}\text { Strongly } \\
\text { agree }\end{array}$ & Agree & $\begin{array}{l}\text { Neither agree } \\
\text { or disagree }\end{array}$ & Disagree & $\begin{array}{l}\text { Strongly } \\
\text { disagree }\end{array}$ \\
\hline Do you think medical student should & 02 & 09 & 52 & 43 & 04 \\
\hline know about research methodology & $1.9 \%$ & $8.18 \%$ & $47.27 \%$ & $39.09 \%$ & $3.6 \%$ \\
\hline Workshop covered all the aspect of & 07 & 62 & 30 & 02 & 09 \\
\hline research protocol write up & $6.3 \%$ & $56.3 \%$ & 27.25 & $1.8 \%$ & $8.1 \%$ \\
\hline Searching literature session was & 04 & 39 & 45 & 15 & 07 \\
\hline adequate to learn & $3.6 \%$ & $35.4 \%$ & $40.90 \%$ & $13.6 \%$ & $6.3 \%$ \\
\hline Data analysis skill during project is & 05 & 49 & 22 & 25 & 12 \\
\hline useful to you in future & $4.5 \%$ & $44.5 \%$ & $20 \%$ & $22.7 \%$ & $10.9 \%$ \\
\hline Report writing skills develop after this & 03 & 58 & 32 & 14 & 03 \\
\hline project work & $2.7 \%$ & $52.7 \%$ & $29.9 \%$ & $12.72 \%$ & $2.7 \%$ \\
\hline You think that team research is better & 15 & 74 & 13 & 7 & 01 \\
\hline than individual research & $13.6 \%$ & $67.27 \%$ & $11.8 \%$ & $6.36 \%$ & $0.9 \%$ \\
\hline It has empowered us to diagnose & 16.5 & 76 & 10 & 6 & 02 \\
\hline health problems with minimal resources & $14.5 \%$ & $69.9 \%$ & $9.9 \%$ & $5.4 \%$ & $1.81 \%$ \\
\hline Helped us develop good & 13 & 75 & 12 & 07 & 03 \\
\hline communication skills & $11.8 \%$ & $68 \%$ & $10.9 \%$ & $6.3 \%$ & $2.7 \%$ \\
\hline Doing project was interesting as there & 14 & 76 & 13 & 05 & 01 \\
\hline is more scope for creativity & $12.72 \%$ & $69.9 \%$ & $11.8 \%$ & $4.5 \%$ & $0.9 \%$ \\
\hline Time was inadequate for completing & 72 & 30 & 05 & 02 & 03 \\
\hline the project & $65.4 \%$ & $27.2 \%$ & $4.5 \%$ & $1.8 \%$ & $2.7 \%$ \\
\hline Expenditure incurred in the project was & 60 & 40 & 03 & 03 & 04 \\
\hline a weakness & $54.5 \%$ & $36.3 \%$ & $2.7 \%$ & $2.7 \%$ & $3.6 \%$ \\
\hline
\end{tabular}

on community health through individual projects and in India it is known as Health Action. ${ }^{12}$ Sumandeep Vidyapeeth is the pioneer in EBES concept in medical education and SBKS Medical Institute \& Research Center, Vododara, Gujarat started the EviGenCHIP to sensitize students for research, searching skills and understanding level of evidence in evidence pyramid in III MBBS. It is established that students undergoing lecture-based learning showed less interest in health research than those undergoing problem-based learning. ${ }^{13}$

Research update $\mathrm{z}$ medical students on the latest advances in medicine and science and provides new interpretations of existing facts. However, we required more efforts in developing countries than developed countries, where EBES has been started earlier in many other ways than developing countries. ${ }^{14-16}$ Our study showed the $90.9 \%$ students believe that research in medical field is important, while approximately $40 \%$ students believed that medical students should not know about research methodology, may be due to variety of factors include lack of knowledge, excessive study burden and many other indifferent attitude, need to be identified and approached. ${ }^{17,18}$ The study observed various barriers for research, they are time and expenditure for study. Similar observations were made by Mostafa SR et al in their study about curriculum overload, time constrain, less time for training and lack of motivation and incentives. ${ }^{19}$

A few students had the willingness to consider research as their career. Lack of proper support systems in our country and lack of clarity of research path seem to be demotivating the students from a research oriented career, though they have the awareness and skills. The reasons quoted by students, like 'lack of any financial/ academic benefit', 'no status/respect', 'no idea of research career' emphasize the need to have student support systems to enhance the number of physician scientists in the long run. In our study we found that more than $80 \%$ students never been a part of research and they agreed that after EviGenCHIP, they acquired the research concept. Almost 56.3\% students agreed that research is useful for medical undergraduates. On the contrary $89 \%$ students are unaware about the publication research and would not consider it as a good carrier option. ${ }^{20}$ Students acquired the searching skills and $90 \%$ students were using PubMed,Google and Wikipedia as a search engines for their EviGenCHIP.

In India, Kumar et al. have reported that considerable proportion of students was not fully aware of the benefits of engaging undergraduate students in research.$^{21}$ Hence, the early hands-on exposure of all students to research process should be ensured in the traditional teaching curriculum. Seminars, Case based learning, symposiums and courses should be more frequently conducted to attract more students toward research activities. ${ }^{22}$ Such seminars may be focused on eliciting the importance of research, explaining different methods of research, and above all, showing the newer students the research work of experienced professionals. This can inspire medical 


\begin{tabular}{|c|c|}
\hline Annexure 1 & List of EviGenCHIP projects \\
\hline 1 & A comparative study of smoking in between medical and non-medical students in Waghodiya \\
\hline 2 & $\begin{array}{l}\text { To detect the Prevalence of COPD in patients of smoking attending respiratory clinic at Dhiraj General Hospital over a } \\
\text { period of } 2 \text { months }\end{array}$ \\
\hline 3 & Study of prevalence of sleep disorders and effect of good sleep hygiene on it in urban population \\
\hline 4 & $\begin{array}{l}\text { To find out the Prevalence of Refractive error in Primary school going children studying in N.G Shah Sarvajanik school } \\
\text { in Waghodiya }\end{array}$ \\
\hline 5 & Evaluation of stress among first year MBBS students \\
\hline 6 & $\begin{array}{l}\text { A community based cross-sectional survey to study the awareness about immunization among the parents having child } \\
\text { under the age of } 10 \text { years in Waghodiyataluka and to educate them regarding the importance and necessity of immunization }\end{array}$ \\
\hline 7 & $\begin{array}{l}\text { To find the prevalence of hypertension in } 200 \text { women above the age of } 18 \text { years living in Piparia and counseling the } \\
\text { identified hypertensive women to seek medical treatment }\end{array}$ \\
\hline 8 & $\begin{array}{l}\text { A comparative study of iron deficiency anemia among the reproductive age group and post menopausal women } \\
\text { attending OPD of Dhiraj general hospital }\end{array}$ \\
\hline 9 & Hospital acquired infection in ICU of Dhiraj general hospital \\
\hline 10 & Screening for prevalence of dementia in urban geriatric population in cities of Gujarat \\
\hline 11 & Tobacco use and study effect of educational interventional in tobacco users \\
\hline 12 & Prevalence of Hypertension and associated risk factors among Medical students \\
\hline 13 & Comparison of two models for screening of Refractive errors in school going children of rural area in Vadodara \\
\hline 14 & $\begin{array}{l}\text { To study the prevalence of anemia in sweeper class female staff of Dhiraj General Hospital and to intervene wherever } \\
\text { possible for a period of } 2 \text { months }\end{array}$ \\
\hline 15 & $\begin{array}{l}\text { To study the awareness about RNTCP among medical, nursing and Physiotherapy students of first year SVU over a } \\
\text { period of } 3 \text { months }\end{array}$ \\
\hline 16 & $\begin{array}{l}\text { A community based survey to determine the prevalence of Obesity by body mass index among executives in public and } \\
\text { private organizations of urban Vadodara }\end{array}$ \\
\hline 17 & $\begin{array}{l}\text { Compliance of Iron folic acid prophylaxis under Adolescent anemia control programme among the adolescent school } \\
\text { girls of a government school of Waghodia }\end{array}$ \\
\hline 18 & $\begin{array}{l}\text { The presence and composition of microbial pathogens on the cell phones of the surgical health care providers at Dhiraj } \\
\text { General Hospital and test for the antibiotic resistance of the isolated organisms }\end{array}$ \\
\hline 19 & Junk Food Consumption amongst Medical Students \\
\hline 20 & $\begin{array}{l}\text { Awareness generation about mosquito breeding places and effect of health education to eliminate or minimize the } \\
\text { mosquito breeding in urban areas of Vadodara city }\end{array}$ \\
\hline 21 & Evaluation of Sleeping quality among final year medical students \\
\hline 22 & Assessment of Prevalence of systemic hypertension in senior citizens of Karelibaug area of Vadodara town \\
\hline 23 & $\begin{array}{l}\text { A cross sectional study to find out the feeding practices and other risk factors responsible for under nutrition in children } \\
\text { of } 0-2 \text { years of age, admitted to a rural tertiary center, Piparia, Vadodara }\end{array}$ \\
\hline 24 & $\begin{array}{l}\text { A community based survey to evaluate awareness of mother having child under the age of } 5 \text { years regarding cause, } \\
\text { effect and management of diarrhea in Waghodiya village and evaluate effect of health education and training on use of } \\
\text { ORS in management of diarrhea }\end{array}$ \\
\hline
\end{tabular}

students to do research, strengthen their careers, and be better doctors in the long run. In short, such activities have a positive impact on students. ${ }^{23,24}$

The findings should be seen in the light of the limitations that it was a small scale study conducted over a short duration of one year. Long-term follow up and objective quantification of the perceived benefits is required.

\section{CONCLUSION}

Feedback of EviGenCHIP showed that students received good community exposure, which otherwise was not possible academically. It was a good learning experience for students. Evidence generating community health projects can be an effective tool for medical writing at undergraduate level. It also improves active learning in public health and the research skills. This teaching and learning model should be implemented in all medical colleges of India.

Overall the first iteration of exposure to evidence generating survey research within the existing curriculum was well-received. Exposing medical undergraduates to the survey research process at undergraduate level will help them in their future research work and in their studies in the clinical settings. Need for 'Research Training' as an integral part of the undergraduate curriculum course has been recently expressed and the present study came out with a possible approach for medical schools in developing countries and its effects.

\section{REFERENCES}

1. Sackett DL, Rosenberg WM, Gray JA, Haynes RB and Richardson WS. Evidence based medicine: what it is and what it isn't. BMJ 1996; 312(7023):71-72.

2. Lakhani JD. Evidence-based practice -new direction in medical education. JIHS 2013;1(2):68

3. Isaacs AN. Strengthening research in Community Medicine. Indian journal of community medicine 2007; 32(4):239-240.

4. Deo MG. Need for research orientated medical education in India. Indian Journal of medical research 2009;130:105-107.

5. Garg BS and Nayar S. Doctors for the rural poor. World Health 
Forum. 1996; 17: 268-270.

6. Narayanan RP. Medical students leading social revolutions. The clinical teacher 2012; 3(1).

7. Dongre AR, Deshmukh PR and Garg BS. Formative exploration of student's perception about Community Medicine teaching at Mahatma Gandhi Institute of Medical Sciences, Sewagram, India. J Health Allied Scs 2008;7(3).

8. Garg BS and Zodpey S. Status paper on public health courses in India. World Health Organization Country Office- India. New Delhi; 2006.

9. Kassebaum DG, Szenas PL, Ruffin AL and Masters DR. The research career interests of graduating medical students. Acad Med 1995; 70:848-852.

10. Hren D, Lukic IK, Marusic A, Vodopivec I, Vujaklija A, Hrabak M, et al. Teaching research methodology in medical schools: Students attitudes towards and knowledge about science. Med Educ 2004;38:81-86.

11. Short term studentship. ICMR. Retrieved 22 November 2010.

12. Health Action by People. Problem Solving for Better Health. Retrieved 22 November 2010.

13. Khan H, Taqui AM, Khawaja MR and Fatmi Z. Problem-based versus conventional curricula: influence on knowledge and attitudes of medical students towards health research. PLoS One. 2007; 2(7): e632.

14. Mostafa SR, Khashab SK, Fouaad AS, Baky MA and Abdel WAM. Engaging undergraduate medical students in health research: Students' perceptions and attitudes and evaluation of a training workshop on research methodology. The Journal of the Egyptian Public Health Association 2005;81(1-2):99-118.

15. Mokry $\mathrm{J}$ and Mokra D. Opinions of medical students on the pre-graduate scientific activities-how to improve the situation? Biomedical Papers 2007; 151(1): 147-149.

16. de Oliveira, Neilton A, Luz MR, Saraiva RM and Alves LA. Student views of research training programmes in medical schools. Medical education 2011;45: 748-755.

17. Khan $H$, Khawaja MR, Waheed A, Rauf $M$ and Fatmi Z. Knowledge and attitudes about health research amongst a group of Pakistani medical students. BMC Med Educ 2006;6:54.

18. Salgueira A, Costa $P$ and Gonçalves $M$. Individual characteristics and student's engagement in scientific research: a crosssectional study. BMC Med Educ 2012;12:95.

19. Fang D and Meyer RE. Effect of two Howard Hughes Medical Institute research training programs for medical students on likelihood of pursuing research careers. Acad Med 2003; 78:1271-1280.

20. Zier K, Friedman E and Smith L. Supportive programs increase medical students' research intrest and productivity. J Invest Med 2006;54:201-207.

21. Kumar HN, Jayaram S, Kumar GS, Vinita J, Rohit S, Satish M, et al. Perception, practices towards research and predictors of research carrier among UG medical students from coastal South India: A cross-sectional study. Indian Journal of Community Medicine 2009; 34(4):306-309.

22. Nair SP, Shah T, Seth $S$, Pandit $N$ and Shah GV. Case Based Learning: A Method for Better Understanding of Biochemistry in Medical Students. Journal of clinical and diagnostic Research 2013;7(8):1576-1578.

23. Marušic $A$ and Marušic $M$. Teaching students how to read and write science: a mandatory course on scientific research and communication in medicine. Academic Medicine. 2003;78(12):1235-1239.

24. Hren D, Lukić IK and Marusić A. Teaching research methodology in medical schools: students' attitudes towards and knowledge about science. Med Educ 2004;38(1):81-86.

\section{Authors Contribution:}

TS - Data collection done, drafted the manuscript, Contributed to the study design; GP - Data collection, review the manuscript; NP - Concept developed, designed the study, drafted the manuscript, \& reviewed the manuscript; AG - Contributed to the study design, Reviewed the manuscript.

Source of Support: Nil, Conflict of Interest: None declared. 